\section{Who leads the drugs league?}

London

$\mathrm{J}_{\text {APAN }}$ is rising up the world league table of originators of successful drugs, according to a survey of 72 pharmaceutical companies and 500 products published this month by the London-based merchant bank Robert Fleming Securities Ltd. Of the world's top 50 best-selling drugs, seven originated in Japan, a country that would not have featured in the table at all a few years ago, says the report. The United States is at the top of the table with 20 of the top 50 drugs in 1987 . Ten come from the United Kingdom, six from Switzerland, five from West Germany and one each from Sweden and Italy.

Of individual companies, Merck, of the United States, has the largest revenue, showing an ability to transiate research into revenue greater than that of any other company. The UK company Glaxo lies fourth behind Ciba-Geigy of Switzerland and Hoescht of Germany, but is growing faster than they are; the report predicts that Glaxo will rise to second place behind Merck in 1988. A major factor in its rise is the "phenomenal success" of its anti-ulcer drug, Zantac, the world's top-selling drug since 1986 , with sales of about $\$ 1,500$ million.

Drugs with markets growing strongly are those for the treatment of viral infections and cardiovascular disorders. Although antiviral drugs were almost nonexistent a few years ago, the market grew by more than 60 per cent last year to $\$ 500$ million and is expected to increase fourfold over the next five years with new drugs for herpes and AIDS.

The market for cardiovascular drugs was worth about $\$ 16,000$ million last year and is expected to grow at an average annual rate of 15 per cent. Calcium antagonists and ACE inhibitors, drugs used to treat high blood pressure, are growing at the expense of beta-blockers. And cholesterol-reducing drugs and thrombolytics, which dissolve blood clots, have "particularly exciting prospects", says the report.

At the other end of the spectrum are drugs in decline, most notably Valium and Ativan, both tranquillizers that have been criticized for their addictive properties.

In general, innovation in the industry has been slow over the past two decades, says the report, reflected in the fact that of the best-selling drugs, 30 out of 50 have been at the top of the league since before 1980 , and 10 of them since 1970 . And when they decline it is often not a result of the emergence of innovative products but because of patent expiry and the subsequent emergence of similar competitors.

Christine McGourty

\title{
Computer software in India
}

\section{New Delhi}

BLESSED with a vast brain pool and with an eye on the growing market, India has launched an aggressive programme for producing computer software for export. The government has decided to set up four technology parks where engineers will write software for export via satellite.

The first software technology park at Pune, near Bombay should, by the end of this year, have 20 Indian companies with shops in the park sharing the satellite terminal directly linking their customers in US cities. In five years, software export from the park is expected to reach $\$ 300$ million. Three more parks are being established at Bubneswar, Bangalore and Chandigarh. Officials of the Department of Electronics (DOE) say that India could become the world's major software producer by the end of 1990 .

The United States is the first target for export, followed by Japan and Europe. Potential US customers are being identified by the state-owned company CMC Limited in preparation for the establishment of an Indo-US software trade network. As part of the export drive, DOE has been organizing seminars abroad to project Indian software capabilities, and has set up a software development agency within the department.

India wants to keep its brightest graduates at home rather than seeing them emigrate to the United States and elsewhere. Software parks can keep them gainfully employed while earning foreign currency for India.

The government has also welcomed foreign computer companies that recruit Indian staff. Two years ago, Texas Instruments (TI) of Dallas set up a subsidiary in Bangalore with a staff of 30 software specialists. An Earth station on top of its office building now sends the programme written by the Indians to TI's mainframes in Dallas via Bedford in England. With cheaper Indian labour, TI expects to recover its investment cost in another two years.

In another project, Indian engineers are generating financial software programmes for the US company Citibank at its subsidiary in a free-trade zone near Bombay airport. Hinditron Services of Bombay has been developing programmes for US companies Tetronix Inc., Digital Equipment Corporation and Hewlett-Packard. Japan has also spotted India's software potential, and PSI Systems in Bangalore develops software exclusively for Japanese computers.

India is also encouraging Indians living abroad to return home and invest their talent and savings in software parks. Two groups have so far responded and will invest $\$ 5$ million in each of the three proposed parks at Pune, Hyderabad and Nilgris (in Tamil Nadu) where the government will install Earth stations to link them with US computer companies.

K.S.Jayaraman

\section{Air pollution takes its toll in the US}

\section{Washington}

"ACross the United States, air pollution is contributing to the decline and ultimate death of forest trees and to widespread losses in crop yields." That is the conclusion of a study* by the World Resources Institute, and, according to the study's authors, the time has certainly come to take steps to mitigate this damage.

Although natural factors still account for most forest decline, airborne chemicals are playing an increasingly important role. Increased ozone is thought to be damaging pines in the San Bernadino National Forest near Los Angeles, as well as white pines in the eastern part of the United States. Red spruce in the east, yellow pines in the southeast and sugar maple in the north-east are also showing signs of damage. In addition to ozone, acidic pollutants in the air, as well as longer term damage from the deposition of these compounds in soil, are posing problems in forests.

Crop damage, primarily from ozone, has also reached significant levels. Using data from the National Crop Loss Assessment Network, the World Resources Institute study estimates that ozone is causing more than $\$ 3,000$ million in losses for major crops. Estimates are that a $\mathbf{4 0}$ per cent reduction in ozone would all but eliminate the cash losses to agricultural crops.

To stem the damaging tide of pollutioncaused destruction, the study calls for an integrated strategy involving decreased emissions from stationary and mobile sources, development of alternatives to burning fossil fuel, and maintaining a closer watch on the shifting picture of the interaction of pollutants with the biosphere. One problem in charting forest damage, says James J. MacKenzie, one of the report's authors, is that there are no national programmes to evaluate forest decline.

Ironically, after years of criticism, environmental groups are now seeing socalled Second Generation nuclear technologies as a potentially non-polluting alternative for power needs should renewable energy alternatives - wind turbines, solar cells, geothermal energy - fail to achieve their promise.

Joseph Palca

"Ill winds: airborne pollution's toll on trees and crops. World Resources Institute, Washington, 1988. 